\title{
Seasonal variations affect the physical and chemical parameters of inland waters: a case study of Warri River in Nigeria
}

\author{
Joyce E. Idomeh ${ }^{\mathrm{a}, 1, *}$, Olufunke B. Shittu ${ }^{\mathrm{b}}$, Nnenna A. Isokpehic ${ }^{\mathrm{c}}$, Kolapo A. Fasina ${ }^{\mathrm{b}}$ \\ ${ }^{\mathrm{a}}$ Marine Environment and Pollution Control, Faculty of Marine Environmental Management, Nigeria Maritime University, Okerenkoko, Delta State \\ ${ }^{b}$ Microbiology, College of Biosciences, Federal University of Agriculture, Abeokuta. Nigeria. \\ ${ }^{c}$ Microbiology, College of Biosciences, Salem University, Lokoja. Nigeria. \\ 1.joyceidomeh@gmail.com \\ * corresponding author
}

ARTICLE INFO

Article history

Received June 05, 2019

Revised August 31, 2019

Accepted November 02, 2019

Keywords:

dry season

rainy season

fresh water ecosystem

Nigerian coastal region

water quality

\section{ABSTRACT}

The Niger-Delta area in Nigeria is rich with rivers, swamps and creeks that are often subject to various forms of pollution. The effect of seasonal variations on the physical and chemical conditions of Warri River was studied in 2015. Temperature and $\mathrm{pH}$ values across all seasons fell within the optimum range formost aquatic organisms. Meanwhile, total dissolved solids exceeded the World Health Organization (WHO) permissible limit, especially during the dry season; indicating possible pollution from inorganic salts, organic matter and other dissolved materials in the water. The low dissolved oxygen value recorded was expected due to the high levels of dissolved solids recorded in the river. Lastly, phosphate, nitrate and sulphate concentrations recorded were below the WHO permissible limits. The chemical and biological parameters recorded indicate that the Warri River poses minimal threat to human and animal life.

This is an open access article under the CC-BY-SA license.

\section{Introduction}

The Niger-Delta (Fig. 1) is the major oil-producing part of the Nigerian Republic, the problem of water in this area is not that of availability, but portability (Uzoekwe and Oghosanine, 2011). Inland waters have been reported to be more dilute as compared with sea water; the biogeochemistry of inland waters such as streams, lakes, and wetlands lies in its cations (calcium, magnesium, sodium and potassium) and anions (bicarbonate, carbonate, sulphate and chloride). Gravity moves elements through river networks over geologic time, thereby transporting these elements through time and space (Schlesinger and Bernhardt, 2013).

The biological and chemical parameters in drinking water include $\mathrm{pH}$, colour, salinity, dissolved oxygen, total solutes, alkalinity, hardness and conductivity of the water. Beyond specified tolerable limits, these parameters indicate pollution (Eze and Okpokwasili, 2010).

Hydrogen-ion concentration is used to describe the acid or base properties of wastewater; $\mathrm{pH}$ between 5 to 7 is an indication of septic conditions while values less than 5 and greater than 10 indicate the presence of industrial waste and non-compatibility with biological operations. $\mathrm{pH}$ of between 6-9 is ideal for the existence of biological life (Gray, 2002). Dissolved oxygen on the other 
hand, is required for the respiration of aerobic microorganisms and is affected by solubility, temperature, partial pressure of the atmosphere and concentration of impurities such as salinity and suspended solids in the water (Hawley and al., 2014).

Oxygen demand in the form of Biological Oxygen Demand (BOD) or Chemical Oxygen Demand (COD) is the amount of oxygen used by microorganisms as they feed upon organic solids in wastewater. The presence of sufficient oxygen promotes the biological decomposition of organic waste (Eze and Okpokwasili, 2010). Total dissolved solids (TDS) and total suspended solids (TSS) are the most common way of classifying solids in water, the amount of solids in drinking water systems has significant effects on the total solid concentration and can be an indicator of discharge from both industrial and domestic sources.

Surface waters contain phosphorus levels in various amounts: it is an essential constituent of living organisms in natural conditions. Phosphorus concentration in water is maintained at an optimal balance for aquatic life. However, when phosphorus input is higher than what living organism populations in the water are able to assimilate, excess phosphorus remains in the water, leading to extensive algal growth also known as eutrophication (Hawley et al., 2014).

Nitrogen is needed by all living organisms for the basic processes of life including growth and reproduction. However, its discharge above the required limit $(10 \mathrm{mg} / \mathrm{L})$ can be undesirable due to ecological and health impacts (Amir et al., 2004). Most organisms cannot use nitrogen in the gaseous form $\left(\mathrm{N}_{2}\right)$ for nutrition, hence they depend on other organisms to convert nitrogen into forms that they can use (Eze and Okpokwasili, 2010).

These biological and chemical parameters in drinking water affect the $\mathrm{pH}$, colour, salinity, dissolved oxygen, total solute, alkalinity, hardness and conductivity of water. Beyond WHOspecified tolerable limits, this can lead to various water-borne diseases including diarrhea, cholera, typhoid fever, shigellosis, cryptosporidiosis, onchocerciasis and dracuncuculiasis (WHO, 2003).

\section{Method}

Delta State shares similar climatic features with other states in the Niger-delta; its vegetation is characterized by mangrove forests, brackish swamp forests and rain forests. It experiences a tropical climate consisting of a rainy season (April to November) and a dry season (December to March). The Warri River stretches within latitude $5^{\circ} 21^{1}-6^{\circ} 00^{1} \mathrm{~N}$ and longitude $5^{\circ} 24^{1}-6^{\circ} 2^{l} \mathrm{E}$ and has its source around Utagba Uno (Aghoghovwia, 2011). Samples were collected in the dry months: January (early dry season) and March (late dry season) and wet months: May (early rainy season) and October (late rainy season) from three different locations along the River Warri.

Triplicate $\mathrm{pH}$, temperature, electrical conductivity (EC) and total dissolved solid (TDS) values were read with the aid of a Hanna Instrument (Model HI 98130, US). Dissolved oxygen (DO) was measured using the Winkler's method; biological oxygen demand (BOD) was measured using the 5-day BOD test, and chemical oxygen demand (COD) was calculated using the titration method. Nitrate, phosphate and sulphate values were determined using a spectrophotometer at $470 \mathrm{~nm}, 660$ $\mathrm{nm}$ and $420 \mathrm{~nm}$ respectively, following methods by Wang et al. (2010). Petroleum hydrocarbon composition of the water body was determined by Pyrolysis Gas Chromatography and Mass Spectrometry (GC-MS) analysis.

Statistical data analysis was performed using Microsoft Excel (2010) and SAS 9.1 (2002-2003, NC USA). Analysis of variance (ANOVA) was considered significant at $\mathrm{P} \leq 0.05$. 


\section{Result}

Seasonal variations in the physical and chemical parameters of Warri River are reported in Table 1. $\mathrm{pH}$ values recorded fell between 6.04-7.13 with highest values during the early rainy season and late rainy season recorded in Location One( $\mathrm{pH} 6.63$ and 7.13, respectively). During the early dry season, lowest $\mathrm{pH}$ values were recorded in Location One $(\mathrm{pH}$ 6.60), while during the late dry season, Location Two recorded highest values $(\mathrm{pH} 7.01)$. The temperature recorded ranged between $27.72{ }^{\circ} \mathrm{C}$ to $30.33{ }^{\circ} \mathrm{C}$; highest temperature $\left(30.33{ }^{\circ} \mathrm{C}\right)$ and lowest temperature value of 27.72 ${ }^{\circ} \mathrm{C}$ was recorded in Location Two during the late rainy season and the early rainy seasons respectively.

Electrical Conductivity values recorded were very high in some locations; Location Three recorded the highest values (5590.0) during the early dry season. Meanwhile, total dissolved solid values were recorded at 13.33 and 2800.33 at Location Three during the late rainy season and early dry season, respectively. Dissolved oxygen minimum and maximum valueswere4.87 and 6.63, recorded during the late dry season and the late rainy season, respectively. COD (range: 6.50 to 30.77 ) recorded higher values than BOD (range: 1.43 to 4.33 ); highest mean values were recorded in Location Three during the late dry season. Nitrate, phosphate and sulphate values fell within the range of $0.21-1.08,0.02-0.77$ and $0.28-5.30$ across all seasons.

Detailed chemical analysis of Warri River samples was carried out for the rainy season and dry season. The analysis revealed that during the early rainy season, several components were detected with the hydrocarbon compound cyclotrisiloxane, hexamethyl- in Locations One, Two and Three at $0.04 \%, 0.05 \%$ and $0.00 \%$.TPH values during the late rainy season in Location One was $0.03 \%$; several compounds were detected in this water sample, including cyclohexene 3-(tertbutyl)peroxide, cyclotrisiloxane, hexamethyl and 2-butenoic acid with minimum abundance values of $0.03 \%, 0.1 \%$ and $0.04 \%$. Samples from Location Two contained benzoic acid, 4-ethoxy- ethyl ester and cyclotrisiloxane hexamethyl amongst others, having amounts of $0.06 \%$ and $0.1 \%$ with a total TPH of $0.16 \%$. Samples from Location Three revealed a total TPH of 3.9\%, with compounds such as benzoic acid 4-ethoxy-ethyl ester and cyclotrisiloxane present at $0.03 \%$ and $0.01 \%$ respectively. Meanwhile, for the dry season, during the early dry season, Locations One, Two and Three samples contained benzoic acid 4-ethoxy-ethyl ester and cyclotrisiloxane, hexamethyl amongst others, at $0.03 \% ; 0.05 \% ; 0.07 \%$ and $0.54 \%, 0.05 \%, 0.06 \%$ with total TPH of $6.25 \%$, $1.31 \%$ and $2.16 \%$ respectively. Samples from the late dry season contained among others, cyclotrisiloxane, hexamethyl- and eicosane at $0.31 \%, 0.38 \%, 0.01 \%$ and $0.03 \%, 0.01 \%, 0.01 \%$ from Locations One, Two and Three. The TPH value in these locations ranged between $0.39 \%$ $1.35 \%$ (Table 2).

\section{Discussion}

In aquatic ecosystems, different biological and chemical parameters including temperature, availability of oxygen and major nutrients to an extent mutually determine the biotic and pollution levels of such ecosystems (Prince, 2010).

$\mathrm{pH}$ is one of the most important operational water parameters as reported by the World Health Organization (WHO, 2003). The high $\mathrm{pH}$ recorded for this water body may be due to the discharge of effluents from various industries and drains as reported by Aghoghovwia (2011). This $\mathrm{pH}$ range can be said to be neutral and agrees with the work of Abowei (2010) where this pH range was reported to be ideal for biological productivity while anything lower is detrimental to aquatic life. We observed the highest $\mathrm{pH}$ range during the late rainy season and late dry season, followed by the early dry and early rainy season.

High mean temperature values were observed in Warri River ( $p>0.05)$. These high values could be attributed to the influx of effluents and other household wastes into the river. This is in line with 
results by Akan et al. (2007) reporting temperature values ranging from $26.40^{\circ} \mathrm{C}$ to $30.1^{\circ} \mathrm{C}$ being a result of discharge of effluents into the River Kaduna. There is no reported FEPA limit for temperature of surface water bodies in Nigeria. The spatial variation in temperature irrespective of season maybe due to high rates of chemical reaction and/ornatural biological activities in the river, as temperature is one of the factors that govern the absorption processes of the aquatic system.

The electrical conductivity (EC) of water is a linear function of the concentration of dissolved ions. If the conductivity of a stream suddenly increases, it is an indication of a source of dissolved ions in the vicinity; therefore, conductivity measurements can be used as a quick way to locate potential water quality problems. Over $60 \%$ of our sampled locations were outside the $1000 \mu \mathrm{s} / \mathrm{cm}$ FEPA limit (1991) for EC surface water; this could have been the result of extreme contamination of the water bodies by oil spillage, as well as other industrial effluents and domestic waste water. During the rainy season the EC values remained high; rainwater was not able to dilute these water bodies to an extent that would wash off the contaminants that had been previously deposited.

TDS concentrations in natural waters often result from industrial effluents, changes to water balance (by limiting inflow, increased water use or increased precipitation), or saltwater intrusion. Variations in TDS values during different seasons were observed to be significant in Warri River. Kataria et al. (1996) reported that an increase in TDS values indicates pollution by extraneous sources. Early dry season recorded the highest TDS range $(46.00 \pm 0.10 \mathrm{mg} / \mathrm{L}-2800.33 \pm 0.58 \mathrm{mg} / \mathrm{L})$, although during the early rainy season, Location Three also experienced high total dissolved solids which exceeded FEPA permissible limits (500 mg/L) (1991). The high TDS values recorded in Warri River recorded during the early rains could have been a result of the activities associated with the market, sawmills and industries along the river, the other seasons revealed relatively lower TDS values.

In rivers, the concentration of dissolved oxygen (DO) is a sum of processes that include re-aeration, transport, photosynthesis, respiration, nitrification, and decay of organic matter. It is the amount of oxygen measured in water, in milligrams per litre (Cox, 2003). All the sampled locations had DO values which fell below the FEPA (1991) limit of $7.5 \mathrm{mg} / \mathrm{L}$. The values were relatively low with a range of $4.87 \pm 0.15 \mathrm{mg} / \mathrm{L}-6.63 \pm 0.15 \mathrm{mg} / \mathrm{L}$. This low dissolved oxygen (DO) content was expected owing to the high level of total dissolved solutes and organic matter undergoing decomposition in the river, thus resulting in more oxygen uptake and less dissolved oxygen in the water. Aghoghovwia (2011) reported similar DO values while studying the physico-chemical characteristics of Warri River in the Niger Delta region of Nigeria. The highest DO value recorded for Warri River was during the late rainy season. The oxygen may have been replenished during this season due to high wind action that is more prevalent during rain, causing sequential changes in the water circulation and thus increasing the oxygen concentration in the water.

Biological oxygen demand (BOD) is referred to as the index of organic pollution of waste water that can be decomposed by bacteria under anaerobic conditions (Sujitha et al. 2012). The BOD of all sampled locations in the early rainy season exceeded permissible limits of $0 \mathrm{mg} / \mathrm{L}$ by FEPA (1991). Warri River recorded very high BOD values in this study, indicating the high levels of pollution of the water body. Maximum BOD was measured during the late rainy season $(4.33 \pm 0.15$ $\mathrm{mg} / \mathrm{L}$ ). The values are slightly lower compared to maximum BOD values during the dry season (4.7 mg/L) reported by Aghochovwia (2011). This higher BOD from our study indicates the presence of pollution stress on the River.

Meanwhile, COD values observed in the river ranged between $5.50 \pm 0.10 \mathrm{mg} / \mathrm{L}$ to $33.50 \pm 0.10$ $\mathrm{mg} / \mathrm{L}$. Chemical Oxygen Demand is defined as the amount of dissolved oxygen required to cause chemical oxidation of organic material in water. Both BOD and COD are key indicators of the environmental health of a surface water supply and provide a useful guide to the proportion of organic material present in waters. Variations in COD values between $5.50 \pm 0.10 \mathrm{mg} / \mathrm{L}$ to $33.50 \pm 0.10 \mathrm{mg} / \mathrm{L}$ were observed to be significant in the Warri River, these values were much 
higher than BOD values. According to Gray (2002), COD is always higher than BOD because COD measures substances that are both chemically and biologically oxidized.

Variations in nitrate values were minimal across the different seasons studied, ranging between $0.21 \mathrm{mg} / \mathrm{L}-0.98 \mathrm{mg} / \mathrm{L}$, which was far below the limit of $>10 \mathrm{mg} / \mathrm{L}$ set by the FEPA (1991). This is in contrast to the results of other studies such as Oloruntoba et al. (2013) that reported 14\% of water sources in selected communities of Ibadan Southeast local government; Ibadan, Nigeria had nitrate concentrations higher than the FEPA limit. Oloruntoba and al. (2013) posited several sources of nitrate pollution: municipal and industrial wastewaters, urban drainage and on-site sanitary systems (pit latrines/septic tanks), animal pens, and runoff or leachate from refuse dumps and manured or fertilized agricultural lands. In this study, all the seasons recorded low nitrate concentrations; thus, excluding other factors, the water from Warri River is fit for domestic use and agricultural purposes. However, if contamination continues at the present rate, the nitrate levels may rise above permissible limits, thereby making the water body unfit for human use. This is a wake-up call to government agencies and Non-Governmental Organizations (NGOs) to arise and curb uncontrolled disposal of wastes into the water body.

Phosphate concentrations in the river ranged from $0.02 \mathrm{mg} / \mathrm{L}-0.77 \mathrm{mg} / \mathrm{L}$. The values measured were well below FEPA limits of $5.0 \mathrm{mg} / \mathrm{L}$. Phosphates are very important in determining several water quality parameters, and occur widely in nature in plants, micro-organisms, and animal wastes. Phosphorus plays a significant role in the eutrophication (over-enrichment) of lakes and, to a lesser extent, rivers (EPA, 2001). Maximum phosphate levels $(3.41 \mathrm{mg} / \mathrm{L})$ were observed during the late rainy season. This may have been as a result of run-offs, industrial effluents and even sewage discharges from several activities around several locations by the river bed.

Sulphate concentrations found in the locations ranged between $0.28 \mathrm{mg} / \mathrm{L}-5.30 \mathrm{mg} / \mathrm{L}$ and were far below the FEPA permissible limit of $500 \mathrm{mg} / \mathrm{L}$. High concentration of sulphate $\left(\mathrm{SO}_{4}{ }^{2-}\right)$ in water may cause serious health concerns to human health, as it causes catharsis (Sujitha and al. 2012). Early rainy season had the highest concentrations of sulphate $(7.19 \mathrm{mg} / \mathrm{L})$. Sulphates are usually present in the form of ionic sulphates of heavy metals such as iron, copper, nickel and lead, as well as other metals such as sodium magnesium. These could be present in sedimentary rocks (iron sulphides) and in water bodies. In water bodies, sulphates imparts oxious odours, especially when DO levels fall to zero. The presence of sulphates in water can also attack the fabric of concrete sewer pipes (EPA, 2001).

Detailed analysis of residual oil components in the water was conducted to determine the oil hydrocarbon compounds present between the sampling periods. During the early dry season, polycyclic aromatic and heavy alkane hydrocarbons such as hexadecane $\left(\mathrm{C}_{16}\right)$ and eicosane $\left(\mathrm{C}_{20}\right)$, heavy alkenes such as squalene $\left(\mathrm{C}_{30}\right)$ and aromatic esters such as benzoic acid, 4-ethoxy-, ethyl ester $\left(\mathrm{C}_{11}\right)$ were detected in high levels, while the lighter saturated and unsaturated aliphatics such as cyclotrisiloxane and hexamethyl- $\left(\mathrm{C}_{6}\right)$ were present in lower amounts. Ionic surfactant ethanol, 2(dodecyloxy)- was also detected in the early dry season. Meanwhile, in the early rainy seasons a small fraction of light alkanes such as hexadecane $\left(\mathrm{C}_{16}\right)$, high molecular weight aliphatics such as squalene $\left(\mathrm{C}_{30}\right)$ and other low-molecular-weight $\mathrm{PAH}$ compounds such as naphthalenes were identified in the river, indicating that although degradation in the bunkered crude was substantial, complete weathering of the remaining oil components may be in the future. Similar report of substantial degradation from the ongoing natural bio-degradative losses was also given by Allinor and his team (2014).

\section{Conclusion}

Analysis of the seasonal variations of various physical and chemical parameters of Warri River provided an insight into the various anthropogenic activities around the area and the impact of these activities on Warri River pollution. The prevailing physical-chemical parameters within the four seasons studied that were significant include dissolved oxygen, total dissolved solids and 
electrical conductivity; these have been reported to enhance response and biodegradation in oil polluted water bodies. Although the oil pollutant remained detectable, biodegradation will continue to drive the concentrations and profiles of hydrocarbons towards reference levels. This study reveals that the lives of inhabitants around the Warri River, who use it for their daily activities, may be seriously threatened in the nearest future.

\section{References}

[1] Abowei, J. F. N. (2010). Some Population Parameters of Distchodus Rostratus from the fresh Water reaches of lower Nun River, Niger Delta, Nigeria. Advance Journal of Food Science and Technology, 2(2), 84-90.

[2] Aghoghovwia, O. A. (2011). Physico-Chemical characteristics of Warri River in the Niger Delta region of Nigeria. Journal of Environmental Issues and Agriculture in Developing Countries, 3, 2-9.

[3] Akan, J. C., Abdulrahman, F. I., Dimari, G. A., and Ogugbuaja, V. O. (2007). Physiological determination of pollutants in wastewater and vegetables samples along the Jakara wastewater channel in Kano metropolis, Kano state, Nigeria. European Journal of Scientific research,23(1), 122-133.

[4] Alinnor, I. J., Ogukwe, C. E., and Nwagbo, N. C. (2014). Characteristic Level of Total Petroleum Hydrocarbon in Soil and Groundwater of Oil Impacted Area in the Niger Delta Region, Nigeria. Journal of Environment and Earth Science, 4(23): 2224-3216.

[5] Cox, B. A. (2003). A review of dissolved oxygen modelling techniques for lowland rivers. The Science of the Total Environment, 314-316, 303-334.

[6] EPA (Environmental Protection Agency). (2001). Contaminant Candidate List Preliminary Regulatory Determination Support Document for Sulfate. EPA 815/01/015. Washington, DC: Office of Water, EPA.

[7] Eze, V. C., and Okpokwasili, G. C. (2010). Microbial and other related changes in Niger Delta River sediment receiving industrial effluents. Continental Journal of Microbiology, 4, 15-24.

[8] FEPA (Federal Environmental Protection Agency). 1991. Proposed National Water Quality Standards.Federal Environmental Protection Agency. Nigeria 251 (77652).

[9] Gray, F. N. (2002). Water Technology: An Introduction for Environmental Scientists and Engineers. Butterworth-Heinemann. Oxford pp. 35-80.

[10] Hawley, E. R., Piao, H., Scott, N. M. et al. (2014). Metagenomic analysis of microbial consortium from natural crude oil that seeps into the marine ecosystem offshore Southern California. Standards in Genomic Sciences, 9, 1259-1274.

[11] Kataria, H. C., Quershi, H. A., Iqbal, S. A., and Shandilya, A. K. (1996). Assessment of water quality of Kolar reservoir in Bhopal (M.P.). Pollution Research, 15(2), 191-193.

[12] Oloruntoba, E. O., Mynepalli, K. C., Sridhar, R., Alabi, T., and Stephen, A. A. (2013). Nitrate concentration in drinking water supplies in selected communities of Ibadan Southeast local government, Ibadan, Nigeria. African Journal of Environmental Science and Technology, 7(7), 702710.

[13] Prince, R. C. (2010). Bioremediation of marine oil spills, pp. 2618-2626. In KN. Timmis (ed.), Handbook of hydrocarbon and lipid microbiology. Springer-Verlag, Berlin, Germany.

[14] Schlesinger, W. H. and Bernhardt, E. S. (2013) Biogeochemistry: An analysis of Global Change. Elsevier Inc. Academic Press, $3^{\text {rd }}$ Edition. Pp 688

[15] Sujitha, P. C., Mitra, D., Sowmya, P. K., and Mini-Priya, R. (2012). Physico-chemical parameters of Karamana river water in Trivandrum district, Kerala, India. International Journal of Environmental Sciences, 2(3), 1417-1434.

[16] Turner, R. E., Overton, E. B., Meyer, B. M., Miles, M. S., and Hooper, B. L. (2014). Changes in the concentration and relative abundance of alkanes and PAHs from the Deep water Horizon oiling of coastal marshes. Marine Pollution Bulletin, 86(1-2), 291-297. 
[17] Uzoekwe, S. A., and Oghosanine, F. A. (2011). The effect of refinery and petrochemical effluent on water quality of Ubeji creek Warri, Southern Nigeria. Ethiopian Journal of Environmental Studies and Management, 4, 2-11.

[18] Wang, Q., Zhang, S., and Klassen, W. (2010). Potential approaches to improving biodegradation of hydrocarbons for bioremediation of crude oil pollution. Journal of Environmental Protection, 2, 4745 .

[19] WHO (World Health Organization). (2003). Total dissolved solids in Drinking-water Background document for development of WHO Guidelines for Drinking-water Quality Originally published in Guidelines for drinking-water quality, $2^{\text {nd }}$ ed. Vol. 2. 